\title{
DJECA BEZ PRATNJE U SVJETLU MIGRANTSKE KRIZE U CENTRU ZA PRUŽANJE USLUGA U ZAJEDNICI ZAGREB - DUGAVE
}

\author{
Gordana Babić \\ Centar za pružanje usluga u zajednici Zagreb - Dugave, Zagreb, Hrvatska \\ $\varangle$ E-mail: gordana.dugave@gmail.com
}

\begin{abstract}
SAŽETAK
Cilj je rada prikazati funkcioniranje postojećeg modela skrbi za djecu bez pratnje - maloljetnih migranata unutar ustanove koja se bavi djecom i mladima s problemima u ponašanju, upozoriti na teškoće u radu i dati smjernice za daljnje postupanje. Centar Dugave zbrinjava djecu bez pratnje - maloljetne migrante još od 1996. godine. U početku su to bila djeca pretežno s područja bivše Jugoslavije, no kako se mijenjala globalna geopolitička i ekonomska situacija, tako se mijenjala i populacija koju smo zbrinjavali.

Posljednjih godina, s obzirom na to što se događa na Bliskom istoku, pretežno prihvaća djecu bez pratnje s područja Afganistana, Sirije, Pakistana, Alžira, Maroka, Libije, Jemena itd.

Nakon dugogodišnjeg rada na zbrinjavanju djece bez pratnje, može se ustvrditi da takav način smještaja nije adekvatan i da djecu bez pratnje - maloljetne migrante - treba smještati i o njima skrbiti u drugim uvjetima, a nikako ne u ustanovi za djecu i mlade s problemima u ponašanju.

Rad je nastao na bazi višegodišnjeg iskustva i autoričina rada s djecom bez pratnje u CPUZ Dugave.

Ključne riječi: djeca bez pratnje, migrantska kriza, protokol o postupanju
\end{abstract}

\section{UVOD}

Prema Zakonu o međunarodnoj i privremenoj zaštiti (NN 70/15, 127/17) dijete bez pratnje je državljanin treće zemlje ili osoba bez državljanstva mlađa od osamnaest godina, koja je ušla u Republiku Hrvatsku bez pratnje odrasle osobe odgovorne za nj, u smislu roditeljske skrbi, u skladu sa zakonodavstvom Republike Hrvatske.

Riječ je o djeci koja putuju sama i potpuno nezaštićena te ih njihova trenutna situacija često ispunjava strahom za vlastiti život, ali i za život njihovih obitelji s kojima u većini slučajeva nisu ni u kakvu kontaktu. Djeca bez pratnje suočavaju se s nizom rizika, poput rizika od trgovanja ljudima, viktimizacijom tijekom puta, nepoznavanjem jezika i kulture zemlje u koju su došli pa sve do nemogućnosti ostvarivanja temeljnih prava na sigurnost, obrazovanje, zdravstvenu zaštitu itd. Nerijetko se govori da su djeca bez pratnje "djeca u riziku” pri čemu se „termin 'u riziku' koristi da bi se opisala djeca i mladi koji doživljavaju velik broj poteškoća, a to djeca bez pratnje svakako jesu" (Veble, 2019).

Centar za pružanje usluga u zajednici Zagreb - Dugave (dalje u tekstu Centar Dugave) određen je kao jedna od dviju kontrolnih točaka (uz CPUZ Split) koja prihvaća djecu bez pratnje, 
zbrinjava ih i smješta u prostoru Prihvatne stanice (koju dijele s djecom s problemima u ponašanju iz Republike Hrvatske).

S obzirom na to da je Hrvatska još uvijek primarno tranzitna zemlja za većinu izbjeglica, procjenjuje se da godišnje kroz Hrvatsku prođe nekoliko stotina djece bez pratnje roditelja ili skrbnika. Međutim, čak i unatoč relativno malom broju djece bez pratnje koji se trenutno nalaze u Republici Hrvatskoj, ističe se neadekvatnost trenutnog rješenja njihova smještaja, primarno u ustanovama socijalne skrbi za djecu s problemima u ponašanju.

Unatoč procesu deinstitucionalizacije i transformacije ustanova socijalne skrbi, koji se u Republici Hrvatskoj provodi već niz godina, većina maloljetnika s problemima u ponašanju i dalje je smještena u specijaliziranim ustanovama za djecu i mlade s problemima u ponašanju u koje se posljednjih godina smještaju i djeca bez pratnje. To donosi dodatno opterećenje stručnim djelatnicima ustanova, ali ima i potencijalno negativan učinak na djecu bez pratnje jer ona u pravilu ne iskazuju smetnje ponašanja. Nije zanemariv ni dodatni pritisak na djelatnike ustanova socijalne skrbi kojima na raspolaganje nisu stavljeni dodatni resursi da bi se uspješnije nosili s izazovima i odgovorili specifičnim potrebama djece bez pratnje smještenoj u ustanovama. Problemi u pružanju adekvatne brige za djecu bez pratnje prepoznati su i u radu okruglog stola „Djeca bez pratnje: djeca stranci odvojena od roditelja" koji je organizirala pravobraniteljica za djecu 2008. godine (Jelavić, 2008).

Ističu se povremeno i negativni utjecaji na djecu bez pratnje jer neki od njih relativno brzo preuzimaju negativne obrasce ponašanja od ostale djece. Stoga pretpostavljamo da bi smještaj (jer im u većini slučajeva tretman ne treba) i skrb u stambenim zajednicama, a primarno u udomiteljskim obiteljima, bio najprikladniji oblik smještaja.

Ne smijemo pritom zanemariti specifične zapreke i teškoće s kojima se svakodnevno suočavaju djelatnici: od jezične barijere i prehrambenih te kulturoloških razlika, vjerskih potreba do problema utvrđivanja identiteta i dobi. Ipak, kulturološke razlike i raznolikosti u prehrani i vjerskim običajima pripadaju sekundarnim potrebama dok je njihova primarna potreba - ona za obitelji i sigurnosti - i dalje nezadovoljena.

Vidljiv je i manjak posebnih skrbnika za djecu bez pratnje, no još više ističe se samo minimalan i formalan odnos djeteta i skrbnika. Stoga zastupamo, s obzirom na opseg obveza posebnih skrbnika, primjenu instituta punog skrbništva za djecu bez pratnje.

U svakodnevnom radu vidljive su i poteškoće u ostvarivanju nekih elemenata zdravstvene zaštite s kojima se suočava velika većina tražitelja azila i osoba pod međunarodnom zaštitom, a isto se transferira i na djecu bez pratnje.

\section{SUSTAV ZAŠTITE DJECE BEZ PRATNJE U REPUBLICI HRVATSKOJ}

Poglavlje koje slijedi donosi pregled najvažnijih međunarodnih i domaćih zakonskih okvira / dokumenata koji reguliraju skrb o djeci bez pratnje.

Konvencija o pravima djeteta (1989) temeljni je pravni akt kojim se štite i osiguravaju prava djece u skladu s načelima zaštite najboljeg interesa djeteta, zaštite od svih oblika diskriminacije, 
prava na život, opstanak i razvoj, prava na sudjelovanje i slobodno izražavanje vlastitog mišljenja. Navedenom konvencijom posebno se ističe pravo na posebnu državnu zaštitu i pomoć djetetu koje je privremeno ili trajno lišeno obiteljske okoline, ili kojemu se zbog njegova najboljeg interesa ne može dopustiti da u njoj ostane. Takvom djetetu će se osigurati zamjenska skrb u skladu s domaćim zakonodavstvom. Također, Konvencijom o pravima djeteta obvezuje se države stranke da će poduzeti odgovarajuće mjere da dijete koje traži izbjeglički status ili koje se, prema važećem međunarodnom i domaćem zakonodavstvu i postupcima smatra izbjeglicom, bilo da je bez pratnje bilo da je u pratnji roditelja ili neke druge osobe, dobije odgovarajuću zaštitu i humanitarnu pomoć u skladu s odgovarajućim pravima utvrđenima ovom Konvencijom i drugim međunarodnim instrumentima ljudskih prava kao i humanitarnim instrumentima čije su spomenute države stranke.

Zakon o socijalnoj skrbi (NN 157/13, 98/19) u čl. 21., st. 1., alineja 2. prepoznaje dijete bez pratnje u sustavu socijalne skrbi kao korisnika socijalne skrbi, odnosno korisnik socijalne skrbi je i "dijete strani državljanin koje se zatekne na teritoriju Republike Hrvatske bez nadzora roditelja ili druge odrasle osobe koja je odgovorna skrbiti za njega". U skladu s navedenim, dijete bez pratnje ostvaruje prava iz sustava socijalne skrbi bez obzira je li izrazilo namjeru podnošenja zahtjeva za međunarodnu zaštitu, je li je tražitelj međunarodne zaštite, ima li status azilanta, odnosno osobe pod supsidijarnom zaštitom ili je bez statusa. U svakom slučaju, dijete bez pratnje ostvaruje određena prava iz sustava socijalne skrbi u skladu s odredbama Zakona o socijalnoj skrbi.

Jedno od prava koje dijete bez pratnje ostvaruje socijalna je usluga smještaja. U skladu sa Zakonom o međunarodnoj i privremenoj zaštiti (NN 70/15, 127/17) dijete bez pratnje, kojemu je odobrena međunarodna zaštita, ima pravo na socijalnu skrb u skladu s propisima kojima se uređuje područje socijalne skrbi hrvatskih državljana. U skladu s Konvencijom o pravima djeteta (1989), Smjernicama za alternativnu skrb o djeci (UNICEF, 2010), okruženje u kojemu se pruža skrb djetetu treba biti najprije obiteljsko; dakle, srodnička skrb i udomiteljstvo, zatim smještaj koji je nalik obiteljskom okruženju, a posljednja slijedi institucijska skrb.

Osim navedenih oblika, Smjernice za alternativnu skrb o djeci (UNICEF, 2010) prepoznaju i oblik samostalnog stanovanja djece uz nadzor, odnosno organizirano stanovanje uz sveobuhvatnu ili povremenu podršku. Djeci bez pratnje nadalje se posvećuje posebna pozornost kao ranjivoj skupini djece.

Smjernicama se želi ojačati skrbnička zaštita djece bez pratnje, kontaktiranje i spajanje $s$ obitelji te uvjeti povratka u zemlju podrijetla. Osim toga, pri određivanju odgovarajućeg oblika skrbi treba uzeti u obzir individualne različitosti i specifičnosti odvojene djece ili djece bez pratnje poput etničkog i migracijskog podrijetla ili kulturne i vjerske specifičnosti.

Smještaj s namjerom posvojenja ili kafale prema islamskom pravu ne smije se uzimati kao polazna mogućnost u slučaju djeteta bez pratnje. Takva mogućnost uzima se u obzir tek kad se iscrpu svi napori usmjereni u pronalaženju djetetovih roditelja, proširene obitelji ili uobičajenih pružatelja skrbi.

Također, Pravilnik o minimalnim uvjetima za pružanje socijalnih usluga (NN 40/14, 66/15) propisuje uslugu privremenog smještaja u kriznim situacijama (prihvat) za djecu bez pratnje, stranim državljanima, u dobi od 14. do 18. godine, dok im se ne osigura smještaj na drugi način ili do 
povratka u zemlju podrijetla, a najduže do šest mjeseci. Navedenu uslugu mogu osigurati pružatelji socijalnih usluga za djecu i mlađe punoljetne osobe s problemima u ponašanju.

Novi Protokol o postupanju prema djeci bez pratnje usvojila je Vlada Republike Hrvatske 2018. godine. Njime se definiraju nositelji obveza, način i rokovi postupanja prema djeci bez pratnje radi pravodobne i učinkovite zaštite njihovih prava i interesa. Kao dodatak Protokolu pripremljeni su i prilozi kao praktični alati namijenjeni krajnjim korisnicima u postupanju prema djeci bez pratnje. Protokolom se definira pojam djeteta bez pratnje te se navodi:

Dijete bez pratnje je državljanin treće zemlje ili osoba bez državljanstva mlađa od osamnaest godina, koja je ušla u Republiku Hrvatsku bez pratnje odrasle osobe odgovorne za njega u smislu roditeljske skrbi sukladno zakonodavstvu Republike Hrvatske, sve dok se ne stavi pod skrb takve osobe, a uključuje i djecu koja su ostala bez pratnje nakon što su ušla u Republiku Hrvatsku (Zakon o međunarodnoj i privremenoj zaštiti, NN 70/15, 127/17).

Djeca bez pratnje predstavljaju posebno ranjivu skupinu djece kojoj je potrebna posebna zaštita i skrb na putu izloženom raznim rizicima, pri čemu mogu biti izloženi različitim oblicima nasilja, gladi, strahu za vlastiti život, često mogu biti meta krijumčara i trgovaca ljudima.

Ciljevi su novog Protokola iz 2018. godine uvođenje jedinstvene prakse svih mjerodavnih tijela i institucija u Republici Hrvatskoj radi pravodobne i učinkovite zaštite najboljeg interesa djeteta, kao i jasno definiranje obveza svih sudionika u postupanju prema djeci bez pratnje prilikom policijskog postupanja, smještaja, međunarodne zaštite, integracije, spajanja s obitelji ili integracije u hrvatsko društvo, osiguranje kvalitetne zdravstvene zaštite djece bez pratnje, čvrst i učinkovit nacionalni sustav s dobrom suradnjom svih mjerodavnih tijela u postupanju prema djeci bez pratnje.

Svi su postupci u Protokolu navedeni i opisani kronološkim slijedom prema logici zakonskih propisa koji su na snazi i dobroj praksi. Svako poglavlje, osim opisanih uloga sudionika postupka, sadrži i kratko objašnjenje samog postupka.

U kontekstu postojanja i primjene međunarodnih i nacionalnih propisa o zaštiti djece bez pratnje u Hrvatskoj, vrijedno je istaknuti istraživanje koje su provele Kraljević, Marinović i Živković Žigante (2011) radi utvrđivanja mogućnosti i ograničenja pojedinih sudionika sustava u pogledu rješavanja problema djece bez pratnje, analize aktualnog stanja te izrade prijedloga za daljnje aktivnosti. U zaključcima istraživanja, među ostalim, navode sljedeće izazove adekvatnoj zaštiti djece bez pratnje: problem pouzdanih statističkih pokazatelja o razmjeru fenomena djece bez pratnje, neprimjerenost smještaja djece bez pratnje u postojećim domovima u sustavu socijalne skrbi te nedostatak kontinuirane izobrazbe stručnjaka da bi se osigurala specifična i dodatna znanja u radu s djecom bez pratnje.

\section{PROCJENA NAJBOLJEG INTERESA DJETETA}

U svim akcijama koje se odnose na djecu, bilo da ih poduzimaju javne ili privatne ustanove socijalne skrbi, sudovi, državna uprava ili zakonodavna tijela, najbolji interes djeteta mora imati prednost (čl. 3. Konvencije o pravima djeteta). Prije donošenja svih važnijih odluka i poduzimanja važnijih mjera koje se tiču djeteta bez pratnje, potrebno je procijeniti jesu li one u najboljem interesu 
djeteta, pri čemu djetetu treba dati priliku da sudjeluje i izrazi svoje mišljenje. Procjena najboljeg interesa djeteta treba biti zasnovana na individualnim okolnostima svakog pojedinog djeteta, pri čemu se moraju uzeti u obzir osobine samog djeteta, dob, zrelost, zdravstveno stanje, obrazovanje, obiteljska situacija, situacija u zemlji podrijetla, rizici kojima je dijete bilo ili je još uvijek izloženo, kao i ostale okolnosti koje mogu utjecati na donošenje odluka ili poduzimanje mjera koje se tiču djeteta bez pratnje. Procjenu najboljeg interesa djeteta obavljaju stručnjaci iz različitih područja koji rade $s$ djecom u suradnji s djetetovim skrbnikom i samim djetetom.

Protokol iz 2018. godine nudi koristan alat za inicijalnu procjenu potreba djeteta bez pratnje koji se u Centru Dugave redovito ispunjava (iako bi on, zapravo, trebao biti ispunjen već pri identifikaciji djeteta u prisutnosti prevoditelja i dežurnoga socijalnog radnika).

\section{SMJEŠTAJ I RAD S DJECOM BEZ PRATNJE U CENTRU DUGAVE}

Djeca bez pratnje smještaju se u ustanovu temeljem rješenja Centra za socijalnu skrb kao privremeni smještaj u kriznim situacijama (Pravilnik o minimalnim uvjetima za pružanje socijalnih usluga, NN 40/14, 66/15), što je regulirano člankom 98. na sljedeći način:

\section{Članak 98.}

(1) Usluga privremenog smještaja u kriznim situacijama (prihvat) pruža se djeci i mlađim punoljetnim osobama s problemima u ponašanju i teškoćama mentalnog zdravlja koja se zateknu u skitnji, bez nadzora roditelja ili drugih odraslih osoba, do povratka u vlastitu ili udomiteljsku obitelj, dom socijalne skrbi ili dok im se ne osigura smještaj na drugi način, u najduljem trajanju do $72 \mathrm{~h}$.

(2) Usluga privremenog smještaja u kriznim situacijama (prihvat) pruža se i djeci bez pratnje, stranim državljanima, u dobi od 14. do 18. godine, dok im se ne osigura smještaj na drugi način ili do povratka u zemlju podrijetla, a najduže do šest mjeseci.

Prihvatna stanica Centra Dugave pruža specifičnu vrstu socijalno-zaštitne intervencije maloljetnicima i mlađim punoljetnicima, državljanima Republike Hrvatske i stranim državljanima.

Riječ je primarno o kratkotrajnu prihvatu mladih u kriznim situacijama (do 72 sata). Kad je riječ o hrvatskim državljanima, najčešće se radi o bijegu od kuće, bijegu iz druge ustanove, počinjenju kaznenog djela i sličnom.

Kada je riječ o djeci bez pratnje - stranim državljanima, Prihvatna stanica zadovoljava primarno osnovne dječje potrebe: smještaj, hranu, odjeću i obuću. Zdravstvena skrb zadovoljava se parcijalno - najčešće u hitnim slučajevima (akutna intoksikacija, urtikarije, otvoreni prijelomi i slično). Izostaje uključivanje u školu zbog kratkoće boravka i prethodno navedenih obilježja populacije. Nema dovoljno dostupnih prevoditelja pa je onemogućena komunikacija o bitnim parametrima (potrebama, emocijama itd.) pri smještaju koja se odvija tijekom 24 sata. 


\section{CENTAR DUGAVE - STATISTIKA PRIHVATA OD 2011. DO 2018. GODINE}

Prije podrobnijeg prikaza izravna postupanja prema djeci bez pratnje, vrijedno je prezentirati statističke pokazatelje o djeci, stranim državljanima, koja su bila prihvaćena u Centar Dugave. Od 1996. do 2018. godine u Centru Dugave prihvaćeno je oko 2150 djece stranih državljana (Tablica 1).

Ukupno je evidentirano oko 40-ak zemalja podrijetla:

— Afganistan, Albanija, Alžir, Bangladeš, BiH, Bugarska, Crna Gora, Čečenija, Danska, Eritreja, Indija, Italija, Irak, Iran, Kamerun, Kina, Kosovo, Libija, Mađarska, Makedonija, Maroko, Myanmar, Moldavija, Njemačka, Nigerija, Obala Bjelokosti, Pakistan, Peru, Poljska, Rumunjska, Srbija, Sirija, Slovenija, Somalija, Šri Lanka, Turska, Tunis i dr.

Prema podatcima Centra, oko 92 \% prihvata odnosi se na mušku populaciju, većinom u dobi od 15 godina nadalje (prema našim procjenama, određeni broj bio je vidljivo punoljetan). Republika Hrvatska i dalje je za većinu tek tranzitna zemlja; samo je u nekoliko slučajeva zabilježeno da je RH bila ciljana destinacija.

Razlozi napuštanja domicilne zemlje redom su: ratni sukobi, politička situacija, vjerski razlozi, ekonomska situacija, a u nekolicini slučajeva postojala je sumnja na trgovanje ljudima.

Tablica 1. Broj prihvaćene djece prema zemlji podrijetla i razlogu napuštanja domicilne zemlje u razdoblju od 2011. do 2018. godine

\begin{tabular}{|c|c|c|}
\hline Zemlja podrijetla & Broj prihvaćenih & Razlog napuštanja domicilne zemlje \\
\hline Islamska Republika Afganistan & 237 & politička situacija i ratna zbivanja \\
\hline Sirijska Arapska Republika & 33 & rat, politička situacija \\
\hline Somalijska Republika & 14 & politička situacija \\
\hline Alžirska Narodna Demokratska Republika & 119 & politička situacija \\
\hline Republika Kosovo & 10 & ekonomska migracija \\
\hline Bosna i Hercegovina & 11 & ekonomska migracija \\
\hline Islamska Republika Pakistan & 14 & politička situacija \\
\hline Republika Italija & 5 & avanturizam \\
\hline Kraljevina Maroko & 12 & politička situacija \\
\hline Republika Irak & 6 & politička situacija \\
\hline Republika Liberija & 13 & politička situacija \\
\hline Republika Slovenija & 3 & avanturizam \\
\hline Republika Tunis & 3 & politička situacija \\
\hline Republika Turska & 10 & ekonomska migracija \\
\hline Rumunjska & 2 & prošnja \\
\hline Republika Bugarska & 2 & ekonomska migracija \\
\hline Češka Republika & 2 & ekonomska migracija \\
\hline Republika Srbija & 2 & ekonomska migracija \\
\hline $\begin{array}{l}\text { Crna Gora, Mađarska, Danska, Kongo, } \\
\text { Myanmar, Njemačka, Belgija, Eritreja, } \\
\text { Nigerija, Bangladeš, Iran }\end{array}$ & po 1 iz svake države & politička situacija, ekonomska migracija, avanturizam, skitnja \\
\hline Ukupno & 429 & \\
\hline
\end{tabular}


Gordana Babić: Djeca bez pratnje u svjetlu migrantske krize u centru za pružanje usluga u zajednici...

Tablica 2. Broj prihvaćene djece prema spolu u razdoblju od 2011. do 2018. godine

\begin{tabular}{|c|c|c|c|c|c|c|c|c|c|}
\cline { 2 - 10 } \multicolumn{1}{c|}{} & $\mathbf{2 0 1 1}$ & $\mathbf{2 0 1 2 .}$ & $\mathbf{2 0 1 3}$ & $\mathbf{2 0 1 4 .}$ & $\mathbf{2 0 1 5}$ & $\mathbf{2 0 1 6 .}$ & $\mathbf{2 0 1 7}$ & $\mathbf{2 0 1 8 .}$ & Ukupno \\
\hline Muški & 52 & 61 & 24 & 51 & 5 & 75 & 96 & 38 & 402 \\
\hline Ženski & 6 & 3 & 5 & - & 3 & 4 & 3 & 3 & 27 \\
\hline Ukupno & 57 & 64 & 29 & 51 & 8 & 79 & 99 & 41 & 429 \\
\hline
\end{tabular}

Tablica 3. Broj prihvaćene djece prema dobi i spolu od 2011. do 2018. godine

\begin{tabular}{|c|c|c|c|c|}
\hline \multirow{2}{*}{ SPOL } & \multicolumn{3}{|c|}{ Dob } & \multirow{2}{*}{ Ukupno } \\
\cline { 2 - 5 } & do $\mathbf{1 4}$ godina & $\mathbf{1 4 - 1 6}$ & $\mathbf{1 6 - 1 8}$ & 402 \\
\hline Muški & 12 & 97 & 293 & 27 \\
\hline Ženski & 3 & 9 & 15 & $\mathbf{4 2 9}$ \\
\hline Ukupno & $\mathbf{1 3}$ & $\mathbf{4 3}$ & $\mathbf{1 5 4}$ & \\
\hline
\end{tabular}

Tablica 4. Duljina boravka djece bez pratnje u razdoblju od 2011. do 2018. god.

\begin{tabular}{|c|c|c|c|c|c|c|c|c|}
\hline \multirow[b]{2}{*}{ SPOL } & \multicolumn{7}{|c|}{ Duljina boravka } & \multirow[b]{2}{*}{ Ukupno } \\
\hline & do 2 dana & 2 - 7 dana & 7 - 30 dana & 7 - 30 dana & $\begin{array}{c}30 \text { dana do } 6 \\
\mathrm{mj} .\end{array}$ & $\begin{array}{c}6 \text { mj. do } 1 . \\
\text { god. }\end{array}$ & $\begin{array}{l}\text { dulje od } 1 \\
\text { god. }\end{array}$ & \\
\hline Muški & 219 & 73 & 54 & 344 & 8 & 2 & 2 & 402 \\
\hline Ženski & 9 & 9 & 6 & 3 & - & - & - & 27 \\
\hline Ukupno & 226 & 61 & 48 & 42 & 8 & 2 & 2 & 429 \\
\hline
\end{tabular}

Iz gore navedenih tablica vidljivo je da većina djece bez pratnje stranih državljana dolazi iz zemalja zahvaćenih ratom, volatilnom političkom situacijom, pretežno iz ekonomski siromašnih zemalja i sl. Većina djece nakon nekoliko dana uglavnom samovoljno napušta Centar jer im je konačni cilj dolazak u razvijenije zapadne zemlje. Tek u nekoliko slučajeva ostali su u Hrvatskoj; neki od njih naučili su jezik, nastavili školovanje te potražili zaposlenje.

\section{POSTUPAK PRIJE SMJEŠTAJA U CENTAR}

Djeca bez pratnje najčešće se zatječu unutar organiziranih skupina koje ilegalno ulaze u Republiku Hrvatsku. Rijetko putuju sama, što je razumljivo. Prilikom zatjecanja na području Republike Hrvatske, odmah se odvajaju punoljetne od maloljetnih osoba, te se prema maloljetnim migrantima primjenjuje poseban postupak. Uobičajena je sljedeća procedura:

- Kada policijski službenik zatekne dijete bez pratnje, odmah će telefonski pozvati opunomoćenoga stručnog radnika centra za socijalnu skrb;

—Za to se vrijeme moraju zadovoljiti osnovne djetetove potrebe: potreba za hranom, vodom, odmorom, utopljivanjem i slično;

— Policijski službenik će inicirati žuran postupak imenovanja posebnog skrbnika djetetu bez pratnje;

U prisutnosti prevoditelja i dežurne socijalne radnice obavlja se inicijalna identifikacija;

- Bez obzira na to je li dijete izrazilo namjeru podnošenja zahtjeva za privremenom zaštitom, prije smještanja u ustanovu odvodi ga se na inicijalni zdravstveni pregled koji je potreban 
zbog utvrđivanja statusa djeteta, ali i u svrhu zaštite druge djece, kao i djelatnika ustanove; za vrijeme opasnosti od epidemije i zaraze koronavirusom, obvezno se konzultira i dežurni epidemiolog koji daje svoje mišljenje o tome je li potrebna izolacija ili karantena.

\section{Inicijalni zdravstveni pregled}

Važan aspekt prije smještaja u Centar predstavlja i inicijalni zdravstveni pregled. Naime, izostanak inicijalnih zdravstvenih pregleda u prethodnom razdoblju doveo je do pojave impetiga, svraba, vodenih kozica, sumnje na koleru i druge bolesti. Iz tog razloga, prije smještaja djeteta bez pratnje u dom socijalne skrbi, posebni skrbnik ili stručni radnik centra za socijalnu skrb, uz asistenciju policijskog službenika, odvest će dijete na obvezni inicijalni zdravstveni pregled u pedijatrijsku ordinaciju ili ordinaciju opće/obiteljske medicine. Pregled obuhvaća i obvezan pregled cijelog tijela radi utvrđivanja eventualnih ozljeda koje, ako su utvrđene, moraju biti evidentirane u povijest bolesti.

\section{Letak dobrodošlice}

Pri prijemu u ustanovu svako dijete dobiva letak na materinskom jeziku te mu se pušta i tonski zapis na jeziku koji razumije da bi ga se što bolje upoznalo s njegovim pravima i svime što ga za vrijeme boravka u ustanovi čeka. Letak je nastao kao rezultat suradnje s UNHCR-om, HCK-om i Centrom za nestalu i zlostavljanu djecu, koji su svaki sa svoje strane dali doprinos tom važnom dijelu početne integracije djece bez pratnje.

Dostupni su tonski zapisi na arapskom, paštunskom, perzijskom, engleskom i hrvatskom jeziku (suradnja s HPC-om). Pokazali su se vrlo korisnim alatom u uspostavi početnog odnosa s djetetom/djecom bez pratnje, naročito u kombinaciji s tonskim zapisom koji se pušta praktički odmah pri dolasku.

Kada se djecu dočeka s tekstom dobrodošlice na njihovu jeziku, postaju manje nepovjerljiva, polako se opuštaju i pretežno sa znatiželjom slušaju i upijaju inicijalne informacije koje im ponudimo. Pokazalo se da je takav pristup značajno olakšao njihovo kasnije uključivanje u aktivnosti i ritam rada ustanove. 
Gordana Babić: Djeca bez pratnje u svjetlu migrantske krize u centru za pružanje usluga u zajednici..

U nastavku je prikazan originalni letak na arapskom jeziku.
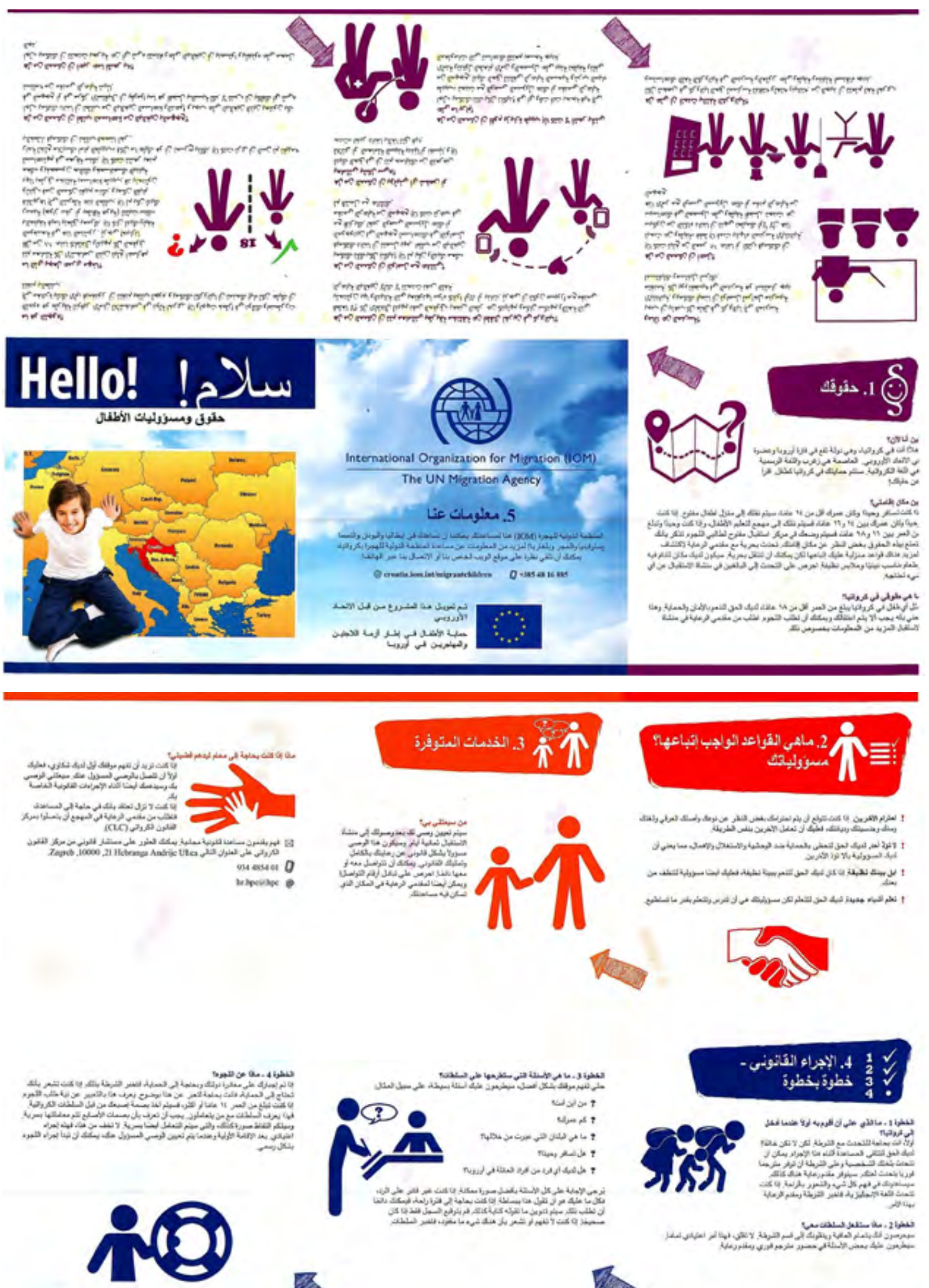

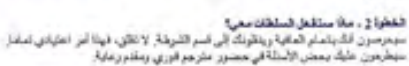
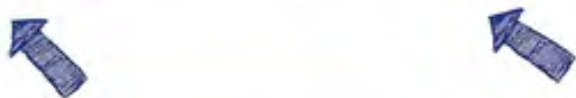

Slika 1. Letak dobrodošlice 


\section{SPECIFIČNA OBILJEŽJA DJECE BEZ PRATNJE PRILIKOM PRIJAMA U CENTAR}

Djeca bez pratnje često manifestiraju sljedeća stanja prilikom prijama u Centar:

— dezorijentiranost - ponekad im nije sasvim jasno ni u kojoj su državi ni u kojem gradu jer ih krijumčari prevare

— osjećaj bespomoćnosti i ranjivosti - na samom dolasku, čini se kao da se osjećaju žrtvom okolnosti, neuspješna prelaska granice, krijumčarske prevare

— anksioznost, briga za budućnost - brinu se što i kako dalje, hoće li moći nastaviti put, kako doći do novaca za nastavak putovanja, hoće li se uspjeti prebaciti do željene destinacije i slično

— frustriranost zbog neinformiranosti - budući da najčešće i ne znaju gdje su ni u koju su ustanovu stigli, u početku pružaju aktivan otpor prema ostanku, no on se vrlo brzo izgubi kada im pustimo tonski zapis na njihovu materinskom jeziku i damo letke u kojima je jasno objašnjeno gdje su i koja su njihova prava

— uznemirenost zbog nemogućnosti uspostavljanja komunikacije - to je problem koji je stalno aktualan jer ako ne znaju engleski, jako teško komuniciraju s nama; međutim, sretna je okolnost što je u skupini uvijek jedan koji govori engleski pa onda prevodi u svim smjerovima

- ljutnja zbog nemogućnosti izražavanja potreba i strahova - naravno da u ovako teškoj i neizvjesnoj situaciji vrlo često imaju potrebu verbalizirati svoje strahove, nadanja, očekivanja i potrebe, no jezična ih barijera u tome koči te su zbog toga ponekad ljuti i uznemireni

- osjećaj besperspektivnosti - ako nemaju novaca ili ne uspijevaju pronaći način da do njega dođu (obično to ide Western Unionom na ime nekog od „posrednika“ iz PTA "Porin”) postaju uznemireni i nervozni jer ne vide način da nastave put

— zabrinutost za druge članove obitelji - najčešće nemaju način provjeriti što je s članovima obitelji koji su ostali u njihovim domicilnim zemljama što ih brine, no tu im aktivno pomažemo i dajemo mogućnost komunikacije raznim besplatnim aplikacijama - WhatsApp, Skype i slično

— nepovjerljivost - s obzirom da su na putu svašta prošli, vidjeli i doživjeli, ne vjeruju nikomu bezrezervno, nego se njihovo povjerenje treba na neki način zaslužiti i opravdati, a to se postiže upravo prethodno opisanim angažmanom odgojitelja da kontaktiraju obitelji, da se u njihovo ime kontaktira posebni skrbnik i slično

- otvoren aktivan otpor - vrlo je rijedak, i takvi najčešće napuštaju prostor trajno, i to vrlo brzo nakon dolaska; najčešće je riječ očito o punoljetnim osobama koje ne žele prihvatiti ritam života i rada u ustanovi za mlade. 


\section{OBILJEŽJA DJECE BEZ PRATNJE SMJEŠTENE U CENTRU DUGAVE}

Većina djece bez pratnje koja biva prihvaćena i smještena u Centru Dugave, a koja su identificirana kao strani državljani, djeluje starije od deklarirane kronološke dobi. Manji broj govori neki od stranih jezika (većinom engleski, a migranti sa sjevera Afrike francuski) što jako otežava uspostavu početnog odnosa. Otprilike $10 \%$ ima više od nekoliko završenih razreda osnovne škole. Među njima nerijetko ima i sasvim nepismenih dok su rijetki oni koji su živjeli u većim gradovima, npr. Kabulu. Većina ih dolazi iz ruralnih područja ishodišnih zemalja te su vidljivo zanemareni, zapušteni, obrazovno deprivirani, no emocionalno topli i simpatični u nastupu. Djeca odgojiteljima pristupaju u većini slučajeva s početnim nepovjerenjem koje se s vremenom razvije u odnos povjerenja, a koji ponekad ima i obilježja srdačnosti. Vole se šaliti međusobno na svoj poseban način, ali rado sudjeluju i kada se odgojitelji šale zajedno s njima. Ponekad nauče pokoje riječi hrvatskog jezika kojima se koriste u situacijama koje postanu vrlo simpatične ili su rezultat prijašnjeg iskustva. Tako npr. neki, koji su dulje vrijeme bili u Bosni, često pozdravljaju na hodniku s uzrečicom „šta ima?" - što je uvijek simpatično.

Djevojaka iz Afganistana, Sirije, Pakistana gotovo da i nema. Pitanje koje nam se često nameće: kreću li te djevojke / mlade žene uopće na put ili ostaju u domovini s namjerom da se kasnije spoje s muškim dijelom obitelji - o čemu odbijaju govoriti.

Specifično je obilježje djece bez pratnje koja dolaze u Centar Dugave, a i općenito u sustav socijalne skrbi, to da dolaze bez ikakvih identifikacijskih isprava ili pak s krivotvorenim dokumentima. Ne iskazuju želju ni potrebu za nastavkom školovanja.

Za razloge kretanja na put iz domicilnih zemalja, djeca bez pratnje navode različite razloge od kojih su najčešći ratni sukobi, vjerski razlozi i ekonomski razlozi.

Povremeno se kod nekih korisnika može primijetiti negativan odnos prema odgojiteljicama koji ne prelazi granicu pristojnosti, no sasvim je jasno da teško prihvaćaju ženski autoritet i da se s time teško mire.

Jedno od najistaknutijih obilježja djece bez pratnje svakako su njihova traumatska iskustva koja proizlaze iz okolnosti njihova života u domovini, ali i iz okolnosti vezanih uza sam put i migraciju. Traumatski događaj, izbjeglištvo iz zemlje podrijetla, duga i vrlo opasna putovanja, razdvojenost od članova obitelji, nehumano postupanje prema njima koje doživljavaju na svojem dugu putu prema zemljama zapadne Europe, doista jest događaj koji je izvan granica uobičajenoga ljudskog iskustva i izrazito je neugodan za svakoga.

Ozbiljna prijetnja vlastitom životu i nama bliskim osobama, ali i svjedočenje takvim događajima, također se podrazumijeva traumatskim događajem. Najintenzivnije posljedice u ljudima izazivaju oni traumatski događaji koji su izazvani ljudskim namjernim djelovanjem. Rat je najznačajniji traumatski događaj izazvan namjernim ljudskim djelovanjem koji dovodi do ljudskih gubitka, obiteljskih tragedija, odvajanja obitelji, stradanja velikog broja ljudi i velikih socijalnih promjena.

Reakcije na traumatsko iskustvo smatraju se univerzalnim i neizbježnim. Ne ovise o spolu, vjeri, naciji, podrijetlu, socioekonomskom statusu ni o dobi (jednako se mogu pojaviti kod osoba 
svih dobi). Mogu biti emocionalne, misaone, tjelesne i ponašajne, a obično su povezane i javljaju se zajedno. One su očekivane, normalne u nenormalnim situacijama kao što su traumatski događaji.

Prava i interesi djece bez pratnje, unatoč svim naporima stručnih djelatnika koji s njima svakodnevno rade, donekle su ograničena specifikumom problematike i populacije koju zbrinjavamo. Problem je i velika fluktuacija, jezična barijera, kao i kulturološke razlike. Sve to ograničava zadovoljenje složenijih potreba i provođenje drugih aktivnosti koje bi bile u njihovu najboljem interesu. Posebni skrbnik trebao bi imati vodeću ulogu u provođenju dodatnih aktivnosti usmjerenih na poboljšanje njihova općeg statusa.

\section{IZAZOVI U RADU S DJECOM BEZ PRATNJE}

Problemi u radu s kojima se svakodnevno suočavamo primarno su posljedica činjenice da je za većinu djece bez pratnje Hrvatska i dalje tek tranzitna zemlja. lako se sa svakim od pristiglih migranata posebno i aktivno radi, a naročito ih se snažno motivira da ostanu, nažalost, njihova usmjerenost da se ili sjedine s dijelom obitelji koji je već u nekoj od zemalja zapadne Europe ili obveza koju su preuzeli, a to je da odu u neku od tih zemalja, rade i pomažu obiteljima koje su ostale u zemlji podrijetla, jača je od svih naših napora, i ta djeca na kraju uvijek odu. Od 2015. godine otkako je počela migrantska kriza / migrantski val, Centar Dugave prihvatio je i zbrinuo oko 550 maloljetnika - stranih državljana od kojih su u RH ostala samo dvojica - jedan Afganistanac i jedan Pakistanac. Svi su drugi otišli, unatoč naporima koji su uloženi da ih se motivira na ostanak.

Kronološka dob koju deklariraju prilikom identifikacije policijskih službenika koji ih pronađu, najčešće ne odgovara stvarnom stanju. Međutim, od toga ne pravimo problem ako se radi o osobi za koju procjenjujemo da u naravi nema više od 22 do 23 godine, dok se pridržava kućnog reda, jer smo svjesni da je njihov boravak ionako privremen. Oni ostaju najkraće, dobro su organizirani i povezani ili s krijumčarima ili s ostatkom svoje skupine i vrlo brzo nastavljaju put. Problemi nastaju kada imamo deklariranog maloljetnika koji čini kaznena djela za koja bi trebao u istražni zatvor, a sudovi im u tom slučaju, zbog navodne maloljetnosti, izriču mjeru privremenog smještaja radi okončanja postupka. Ista se provodi dok osoba ne počne praviti probleme, a u tom se slučaju obraćamo ovlaštenom državnom odvjetništvu i sudu i tražimo da se mjera obustavi od daljnjeg provođenja i u tom slučaju se osoba ili prebacuje u istražni zatvor ili u Prihvatilište za strance u Ježevo.

Također, otežavajuća okolnost je i boravak u istom prostoru s djecom i maloljetnicima s problemima u ponašanju. Naime, dolazi do nepoželjnih interakcija među migrantskom populacijom, koja u pravilu nema smetnje ponašanja, te ih korisnici iz Hrvatske često instrumentaliziraju, a ponekad čak i prisilno uvuku u činjenje kaznenih djela. S druge pak strane, ima slučajeva da djevojke iz Hrvatske (koje su često promiskuitetne, impulzivne i nedovoljno kritične) odu s migrantima te ih nema određeno vrijeme, a roditelji djevojaka zahtijevaju promptnu reakciju društva, njihovo pronalaženje i povratak u ustanovu te odmicanje od stranih državljana, što je nemoguće jer ne postoji prostorni kapacitet u ustanovi za premještanje migranata.

Jezične zapreke rješavamo ili putem internog prevoditelja (član skupine koji govori engleski) ili uz pomoć službenih prevoditelja kada su osjetljivije teme u pitanju pa onda istoga najčešće nazovemo na mobitel, uključimo zvučnik i ostvarimo poziv koji je koristan i nama i djetetu. Tu je i 
prevoditeljski alat Google translate koji nije sasvim pouzdan, stoga se njime najrjeđe služimo, no i on pomogne $u$ akutnoj situaciji.

Nedostupnost prevoditelja znatno otežava svakodnevni rad, a naročito suptilniju komunikaciju kad djeca povremeno imaju potrebu razgovarati o teškoćama ili traumama kojima su bili izloženi na svojem dugu putu ili imaju potrebu „proraditi traumu”.

S obzirom na to da nemamo nikakvih heteroanamnestičkih podataka, uključivanje u obrazovni sustav je otežano jer je gotovo nemoguće utvrditi njihov stvarni školski status, a uz to, zbog diskrepancije između iskazane i stvarne kronološke dobi te činjenice da se svi spremaju na nastavak putovanja, oni najčešće i nisu spremni sjesti u školske klupe. Također, zbog inertnosti sustava izrazito je otežano uključenje djece u osnovnu školu, a također su i neka prava iz zdravstvene zaštite u suženu djelokrugu.

Blizina Prihvatilišta za tražitelje azila "Porin" povećava rizik i opasnost u uvlačenje neke djece bez pratnje u trgovanje ljudima i kriminalnu aktivnost. Malobrojni među njima, koji su evidentno i prije dolaska iskazivali sklonost asocijalnim i antisocijalnim ponašanjima, pokušavaju nastaviti i dalje te pokušavaju i druge uvući u krug nedopuštenih radnji. To odmah prekidamo na način da policiju obavještavamo o našim saznanjima, a od posebnog skrbnika tražimo poduzimanje daljnjih radnji u smislu premještanja iz ustanove.

Različite su potrebe i planovi djece tražitelja međunarodne zaštite i djece pod međunarodnom zaštitom u Hrvatskoj, što iziskuje različite programe rada i iznalaženje aktivnosti radi zadovoljavanja njihovih potreba i zaštite njihovih interesa. Djeca tražitelji međunarodne zaštite posebno su ranjiva skupina budući da emocionalno teško proživljavaju razdoblje od traženja do dobivanja zaštite. Potrebne su im stalne informacije o tijeku postupka.

Njihov osjećaj nepripadanja ni jednoj socijalnoj sredini pojačan je i ometajući u smislu usmjeravanja na budućnost, planiranje, viđenje perspektive. Plan je rada s djecom bez pratnje poput plana rada s djecom državljanima Republike Hrvatske. U adaptaciji u novoj sredini i daljnjem razvoju potrebna im je intenzivna stručna pomoć i podrška tijekom odrastanja, usvajanja vještina i navika, obavljanja razvojnih zadataka, obrazovanja i socijalizacije. Djeca bez pratnje verbaliziraju brigu za članovima obitelji. Opterećenost strahom i brigom zaokuplja ih i ometa u motivaciji za ponuđenim aktivnostima. Tijekom dana su u stalnim pokušajima ostvarivanja veze telefonskim kontaktima i društvenim mrežama. Važno je s djecom razgovarati o članovima obitelji, kontaktima koje ostvaruju s njima i povratnim obiteljskim porukama koje bitno utječu na njihove planove za budućnost.

Rad s djecom bez pratnje na području obrazovanja iziskuje iznalaženje načina učenja hrvatskog jezika putem redovnih institucija (škole, tečajevi) i alternativnih načina (učenje putem programa u institucijama u kojima su smješteni), druženjem s vršnjacima, te svakodnevnim kontaktima s odgojiteljima. Za djecu bez pratnje, kao i za svu ostalu djecu koja su proživjela traumu, škola je iznimno važna jer predstavlja stabilnost u njihovu trenutno neizvjesnu životu. Dodatna specifična situacija je s djecom koja u zemlji podrijetla nisu bila uključena u obrazovni proces ili su nepismena pa je otežano motiviranje za učenje hrvatskog jezika.

Posebni skrbnici i osobe koje rade s djecom trebaju se upoznati s osnovnim kulturološkim, vrijednosnim i društvenim specifičnostima zemalja iz kojih djeca dolaze da bi mogli razumjeti 
stavove, uvjerenja, navike, kulturu ophođenja, stil življenja, vjerske običaje. Tu se ističe velika uloga kulturnih medijatora. S obzirom na to da su djeca proživjela višestruka traumatska iskustva u najosjetljivijoj fazi razvoja adolescencije, a dolaskom u drugu zemlju izložena su novim stresnim situacijama, bitno im je pravovremeno i na adekvatan način pružati zaštitu i sigurnost, te im omogućiti nastavak procesa sazrijevanja, aktualizaciju u novoj sredini življenja svakodnevnom podrškom, usmjeravanjem i poučavanjem, a prema potrebi omogućiti im i stručnu psihološku pomoć putem zdravstvene ustanove i ustanove socijalne skrbi.

\section{ZAKLJUČAK}

Bez obzira na razloge napuštanja zemalja podrijetla, djeca bez pratnje naročito su ranjiva skupina: zatečena su u stranoj zemlji, odvojena od roditelja i drugih bliskih osoba, dodatno traumatizirana iscrpljujućim putovanjem prema zemljama Europske unije, na kojem su nerijetko izložena brojnim rizicima, od loših životnih i higijenskih uvjeta opasnih za život i za zdravlje, do različitih oblika nasilja, eksploatacije i trgovine ljudima. Svakom djetetu, bez obzira na njegov trenutni status u Republici Hrvatskoj ili razloge napuštanja domicilne zemlje, trebaju biti omogućena sva prava koja im jamči Konvencija o pravima djeteta, uvijek imajući na umu načelo najboljeg interesa djeteta. lako je skrbnička zaštita najvažniji instrument zaštite djeteta, skrbnicima je potrebno omogućiti svu moguću pomoć mjerodavnih institucija koje, svaka u svojem području, trebaju brinuti o dobrobiti djeteta bez pratnje.

U postupanju prema djeci bez pratnje uspostavljena je ipak relativno dobra i funkcionalna reakcija društva na njihove potrebe. Od važnijih, za djetetov najbolji interes, možemo navesti:

- imenovanje posebnog skrbnika za postupke tijekom odobrenja međunarodne zaštite: mora biti žurno doneseno rješenje i dijete mora biti upoznato s tim pravom - u praksi su česti slučajevi da djeca napuste mjesto boravka prije okončanja postupka međunarodne zaštite iz razloga jer posebni skrbnik nije imenovan

— prioritetan postupak u odnosu na ostale zahtjeve za odobrenje međunarodne zaštite zakonom je propisan rok od 15 dana za podnošenje zahtjeva računajući od izražavanja namjere

— osiguranje prevoditelja u slučaju kada dijete ne razumije hrvatski jezik

— izdavanje iskaznice tražitelja međunarodne zaštite - ista ne služi kao identifikacijski dokument, već samo služi kao dokaz o pravnom statusu. Izdaje se u roku od tri dana od podnošenja zahtjeva

— izdavanje potvrde o smještaju u Prihvatilište za tražitelje azila ili Centar Dugave

- besplatna pravna pomoć (podrazumijeva odvjetnika, prevoditelja, sastavljanje tužbe i zastupanje pred upravnim sudom)

— materijalni uvjeti prihvata

— pravo na obrazovanje kao i hrvatski državljani

— primjerena zdravstvena skrb. 
Mislimo da bi za kvalitetnije zbrinjavanje djece bez pratnje - maloljetnih migranata, na tragu profesionalnosti, ekonomičnosti, racionalnosti, efikasnosti te uzimajući u obzir njihove potrebe i prava, bilo potrebno oformiti poseban prihvatni centar za sve koji se zateknu u Republici Hrvatskoj, gdje bi imali i prevoditelje, posebne skrbnike, regulirano pravo na školovanje te pravnu pomoć u rješavanju njihova statusa. Time bi, prema našem mišljenju, započela njihova rana integracija na kvalitetan način, a što u ustanovama socijalne skrbi, u istom prostoru s djecom i mladima s problemima u ponašanju, bez prevoditelja, bez učitelja hrvatskog jezika i bez kulturnog medijatora, nije moguće te se oni, umjesto da se integriraju, de facto dobrovoljno segregiraju, s obzirom na to da se ne žele miješati s hrvatskom djecom, koja evidentno imaju odstupanja u ponašanju.

Stoga smatramo da je potrebno:

— prestati s praksom smještanja djece bez pratnje u ustanove za djecu i mlade s problemima u ponašanju

— organizirati posebnu ustanovu s posebno educiranim visokomotiviranim ljudima koji žele raditi upravo taj posao

- za vrijeme adaptacijskog perioda (do 30 dana) provesti trijažnim postupkom procjenu potreba uporabom check-listi, posebno konstruiranih upitnika, metodom samoiskaza i sl. i napraviti hodogram postupanja za svako pojedino dijete.

Na taj bi se način reducirala frustracija koju osjećaju djeca bez pratnje u ustanovama za djecu s problemima u ponašanju, ali također i osjećaj nemoći profesionalnih odgojitelja kojima u radu s djecom bez pratnje izostaje osnovni alat, a to je moć kvalitetne komunikacije.

U takvoj bi ustanovi / prihvatnom centru djeca u idealnim uvjetima imala dostupne prevoditelje (ne nužno fizički, nego preko Skypea i slično), aktivno bi učila hrvatski jezik i pripremala se za integraciju u školsku sredinu, istovremeno bi bili sa svojim sunarodnjacima, što bi im davalo osjećaj sigurnosti, mogli bi jesti tradicionalna jela i hrvatska jela, bila bi im dostupnija pravna pomoć kao i skrbnici.

Time bi se izbjegle višetjedne frustracije, vjerojatno smanjila incidencija bjegova, sustav bi bio ne samo efikasniji i jeftiniji nego i humaniji, a djeca bi bila zbrinuta brzo, učinkovito, kvalitetno i u skladu sa svim konvencijama.

Na žalost, još uvijek, kod nekih stručnjaka postoje određeni strahovi koji se uspješno prevladavaju izravnim radom s djecom bez pratnje. Neki od strahova koji se navode su: strah od terorizma, radikalizacije, bolesti, silovanja itd., što je rezultiralo i odlukama da u pojedinim ustanovama s djecom bez pratnje rade samo muškarci. Djeca bez pratnje uglavnom su segregirana prema smještaju, no ipak djelomično integrirana svakodnevnim aktivnostima. U pojedinim odgojnim ustanovama dolazi i do incidenata i sukoba među djecom bez pratnje i djecom hrvatskih državljana, i to zbog rasističkih stavova djece hrvatskih državljana ("skinsi", BBB i slične marginalne skupine mogu biti jako negativno nastrojeni prema djeci bez pratnje).

Stoga smatramo da bi zaokret u načinu trijaže, prihvata i tretiranja djece bez pratnje, u smislu punog razumijevanja i uzimanja u obzir njihovih stvarnih potreba i životnih prava u posebno 
oformljenoj ustanovi nakon koje bi se moglo razmišljati o njihovu premještaju prema stambenim zajednicama ili udomiteljskim obiteljima, bio istinski iskorak prema kvalitetnijem životu i perspektivi djece bez pratnje zatečene na području Republike Hrvatske.

Nažalost, praksa nam je pokazala da je više od 500 djece bez pratnje, koliko je prošlo kroz Centar Dugave od 2015. godine do danas, u Republici Hrvatskoj ostalo samo dvoje - jedan je u nastavku opisani maloljetnik X.Y., a drugi je mladić koji je ostao bez noge u Tovarniku uskačući u vlak pa ga obitelj, koja je u Njemačkoj, više nije htjela. Obojica su ostvarila pravo na međunarodnu zaštitu, integrirani su i rade, no to je realitet - djeca bez pratnje svoju sreću u pravilu traže u zemljama zapadne Europe.

\section{Primjer dobre prakse:}

Dječak X.Y. (pri dolasku star 16,5 godina) pronađen je krajem 2016. godine u kombiju s 56 drugih izbjeglica u iznimno tešku stanju, pothranjen, dehidriran i potpuno iscrpljen. Doveden je k nama nakon hospitalizacije u siječnju 2017. godine. Nakon adaptacijskog razdoblja s njim su započete ciljane aktivnosti - terapeutski razgovori s našom psihologinjom, uključivanje u aktivnosti slobodnog vremena te pripremno učenje hrvatskog jezika. Dobro se integrirao u školi, hrvatski jezik jako dobro je svladao.

U veljači 2017. godine upisan je u pohađanje I. razreda Tehničke škole za zanimanje računalnog tehničara (suženi opseg). Nakon iskazane namjere, podnesen je zahtjev za privremenom zaštitom. Imao je dva intervjua u Službi za strance i azil, odobrena mu je supsidijarna zaštita. Kada je postao punoljetan, dobio je stan na korištenje i pomoglo mu se u pronalaženju posla. Završio je uz našu pomoć i tečaj za konobara te sada radi stalno, a povremeno i sezonski na moru te je u potpunosti samostalan i zadovoljavajuće integriran.

Cijelo se vrijeme s njim intenzivno radilo, bio je uključen u psihoterapiju, volonterski rad i razne slobodne aktivnosti. Također, aktivno je sudjelovao u radu Udruge Are You Syrious.

Važno je naglasiti da je u ovom slučaju želja i potreba mladića da ostane u Republici Hrvatskoj bila presudna. Bez njegove samoaktivnosti i visoke motivacije, rezultat bi bio značajno skromniji. Međutim, u cijelom tom procesu čini se da smo oboje, ja kao posebna skrbnica i on kao moj štićenik, zajedničkim snagama iznjedrili strategiju postupanja i na tom dugom putu, koji je trajao više od dvije godine, jedan drugoga međusobno poticali i hrabrili da ne odustanemo. Važno je uvijek naglasiti da mnoga od djece bez pratnje zaista u danom momentu nemaju nikoga na svojoj strani i da je posebni skrbnik jedina osoba koja može i mora aktivno pomoći djetetu da se snađe i prihvati realitet, odnosno pomoći mu da se za nj nađe najbolje rješenje koje je na tragu zastupanja njegova najboljeg interesa. 


\section{LITERATURA}

Deklaracija o pravima djeteta (1959). Preuzeto s mrežne stranice: http://www.cirp.org/library/ethics/ UN-declaration/ (01.03.2020.)

Jelavić, M. (2008). Djeca bez pratnje: djeca stranci odvojena od roditelja. Zagreb: Pravobranitelj za djecu.

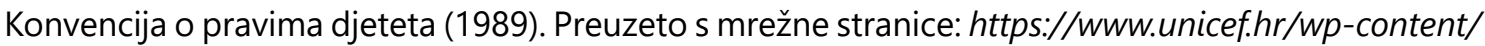
uploads/2017/05/Konvencija_20o_20pravima_20djeteta_full.pdf (01.03.2020.)

Kraljević R., Marinović L., Živković Žigante, B. (2011). Djeca bez pratnje strani državljani u Republici Hrvatskoj: razumijevanje problema, mogućnost djelovanja i potrebne mjere pomoći i zaštite. Zagreb: UNHCR.

Pravilnik o minimalnim uvjetima za pružanje socijalnih usluga, Narodne novine, 40/14, 66/15, 56/20.

Protokol o postupanju prema djeci bez pratnje (2018). Vlada RH. Preuzeto s mrežne stranice: $h t t p s: / / ~$ mdomsp.gov.hr/UserDocs/mages/djeca\%20i\%20obitelj/Protokol\%20o\%20postupanju\%20prema\%20djeci\%20bez\%20pratnje.pdf (01.03.2020.)

Smjernice za alternativnu skrb o djeci (2010). Zagreb: Ured UNICEF-a za Hrvatsku.

Veble, A. (2019). Djeca bez pratnje. Diplomski rad. Zagreb: Edukacijsko-rehabilitacijski fakultet Sveučilišta u Zagrebu.

Zakon o međunarodnoj i privremenoj zaštiti. Narodne novine, 70/15, 127/17.

Zakon o socijalnoj skrbi, Narodne novine, 157/13, 152/14, 99/15, 52/16, 16/17, 130/17, 98/19. 
Gordana Babić Zagreb - Dugave Center for Providing Services in the Community

\title{
UNACCOMPANIED CHILDREN IN THE LIGHT OF THE MIGRANT CRISIS AT THE ZAGREB - DUGAVE CENTER FOR PROVIDING SERVICES IN THE COMMUNITY
}

\begin{abstract}
This paper aims to present the functioning of the existing model of care for unaccompanied children - minor migrants within the institution that deals with children and youth with behavioral problems, to point out the difficulties in its work and to provide guidelines for further action.

The Dugave Center has been taking care of unaccompanied children - minor migrants since 1996. In its early days, the minor migrants mostly came from the former Yugoslavia, but as the global geopolitical and economic situation changed, so did the population we cared for.

In recent years, given the events in the Middle East, the Center has mostly accepted unaccompanied children from Afghanistan, Syria, Pakistan, Algeria, Morocco, Libya, Yemen, etc.

After many years of looking after unaccompanied children, one can conclude that this type of accommodation is not appropriate and that unaccompanied children - minor migrants - should be accommodated and cared for in different conditions and not in an institution for children and youth with behavioral problems.

The paper builds upon many years of experience and the author's work with unaccompanied children in the Dugave Center.
\end{abstract}

Key words: unaccompanied children, migrant crisis, treatment/conduct protocol 